\title{
Editorial
}

\section{Confucianism and Daoism: From Max Weber to the Present}

It has been over a century since the 1915 publication of Max Weber's The Religion of China: Confucianism and Daoism. In the past decades, we have been wrestling with Weber not only over the issue of the rise of the spirit of modern capitalism in China, but also the issue of Confucianism as a religion in China. However, the second half of Weber's seminal text, which is on Daoism, is often ignored. For Weber, Confucianism as the orthodoxy and Daoism as the heterodoxy are two halves of Chinese society that cannot be separated. Their interdependence creates the very fabric of Chinese social, political, and religious life.

In this special issue, we have gathered scholars of Confucianism as well as of Daoism to have an open conversation with one another. These papers originated from the symposium "Confucianism and Daoism: From Max Weber to the Present," sponsored by the Purdue University Center on Religion and Chinese Society, which took place on March 11, 2018. It does not happen often that scholars of Confucianism and scholars of Daoism come together for discussions of Weber as well as their own respective research projects. We were especially fortunate to have a group of interdisciplinary scholars from fields as diverse as sociology, religious studies, East Asian Studies, history, and philosophy.

In "The Last Confucian in the Rice Paddy of Java," Yong Chen examines the case of Confucianism in contemporary Indonesia through the lens of an anthropology of Confucianism. He asks how "popular Confucianism," which has components of religious traditions beyond Confucianism, can inform us about the larger sociopolitical and cultural conditions of contemporary Confucianism. By pushing the boundaries of what it means to live a Confucian life, Chen suggests that Confucianism as lived experiences is often far more porous and expansive than what is commonly assumed. In "From Female Daoist Rationality to Kundao Practice," Robin Wang compares two cases of female Daoist 
monastic life, one from the eleventh-twelfth century, of Cao Wenyi, a woman Daoist master, and the other from the twenty-first century, of the women at the Kundao Academy in Nanyue, an academy for women Daoist monastics. Wang shows the continuity as well as differences in the theory and practice of female Daoist monastic life across time. For these women, Daoism represents an alternative way of life outside the traditional Confucian roles, both in the past and in the present. In "From Alchemy to Science: Daoist Healthcare in Contemporary China," Jonathan Pettit focuses on the Daoist sacred site Mount Yaowang in Shaanxi Province and the long tradition of Daoist medical healing there. Connecting history with the present, Pettit examines how Daoist temples refashion Daoist knowledge today in order to promote it as scientific medical expertise in the contemporary religious and commercial marketplaces. Through his analysis, we see how the Confucian understanding of medicine has historically marginalized and conditioned Daoist healing practices. In these two studies of Daoist life, the Daoist practitioners' engagement with the dominant Confucian tradition may be explicit or implicit, but it is never absent.

The last two papers of this special issue engage with Weber more directly. Both wish to go beyond the Weberian arguments regarding religion and capitalism, and both turn to the interdependence and hybridity of religious life in the Chinese cultural context. In "Religion and the Chinese Diaspora in Southeast Asia," Kenneth Dean makes use of the concepts of "civilizational techniques" and the Chinese "religious field" in his analysis of rich ethnographic data from Malaysia and Indonesia. He argues that "[w]hile Weber's underlying questions remain important in these cases, closer attention to civilizational techniques-including techniques of the body, networking, and mimesis within processes of hybrid rituals, all occurring in rapidly transforming multicultural contexts - can provide deeper insights into unexpected aspects of religious and social change in Southeast Asia." His call for "an approach to the spread of civilizations that embraces the hybridities of the encounters between civilizational technologies and the local construction of culture under constantly changing circumstances" shows great promise for understanding not only religious life in the Chinese diaspora, but also global religious life in general.

In "Thinking with Weber's Religion of China in the Twenty-First Century," Anna Sun proposes to take the development of Confucianism as the dependent variable in our analysis (or alternatively Daoism), rather than the development of modern capitalism, which was Weber's original focus. However, Weber's notion of Confucianism and Daoism as an interconnected wholethe orthodoxy and heterodoxy of Chinese society—can be helpful in the 
construction of an ecological framework for understanding the dynamics of the Chinese religious systems. The notion of "linked religious ecology" is helpful in reassessing how Confucianism and Daoism are interconnected rather than isolated religious phenomena, not set apart from other religious traditions and other aspects of social life but fully integrated with them, for they are both essential parts of an active and ever-evolving whole. By considering the developments of Confucianism, Daoism, and other religious traditions such as Buddhism, Christianity, and Islam as interdependent social processes with dynamics akin to ecological systems, we may be better equipped to examine Chinese religious life as currents flowing in the same river rather than separate streams.

Such ecological thinking or emphasis on the hybridity of civilizational techniques may not have been Weber's original intention when he brought Confucianism and Daoism together in his treatise on China. But it is certainly our goal to think about religions in China as multifarious, permeable, hybrid, everchanging, and ever-evolving. This is especially the case now, given the increasing cultural and religious mobility in the twenty-first century. We hope this special issue will stimulate a more empirically productive conversation about the Chinese religious fields, both in China and in the Chinese diaspora. This is a conversation started by Weber, but it certainly has been expanded beyond his horizon, although not without his continuing challenges and inspiration.

\section{Anna Sun}

Associate Professor, Department of Religious Studies, Duke University,

Durham, NC, USA

anna.x.sun@duke.edu 